\title{
The Morphometric Character and Mitochondrial 16S rRNA Sequence of Portunus pelagicus
}

\author{
Andi Aliah Hidayani ${ }^{\text {a) }}$, Yushinta Fujaya ${ }^{* a)}$, Andi Ivo Asphama ${ }^{\text {a) }}$, Dody Dharmawan Trijuno ${ }^{\text {a) }}$, \\ Andi Tenriulo ${ }^{\text {b) }}$, and Andi Parenrengi ${ }^{\text {b) }}$ \\ ${ }^{a}$ Department of Fisheries, Faculty of Marine and Fisheries Science, Hasanuddin University, Kampus UNHAS Tamalanrea \\ Makassar 90245, INDONESIA \\ ${ }^{b}$ Research Institute for Coastal Aquaculture, Maros 90511, Indonesia \\ * Correspondence to : yushinta.fmuskar@gmail.com
}

\begin{abstract}
Andi Aliah Hidayani, Yushinta Fujaya, Andi Ivo Asphama, Dody Dharmawan Trijuno, Andi Tenriulo, and Andi Parenrengi. 2015. The Morphometric Character and Mitochondrial 16S rRNA Sequence of Portunus pelagicus. Aquacultura Indonesiana, 16 (1): 1-9. Blue swimming crab (Portunus pelagicus) colors have variations from different habitats and they have different vitality. The purpose of this study was to analyze the diversity of the $P$. pelagicus using morphometric and 16SrRNA mitochondrial sequence. There were three groups of blue swimming crab characterized by differences in color and density patterns of spots. The result of Canonical discriminant analysis showed that there were morphometric differences among the three groups. The main distinguishing morphometric characteristics are the ratio of carapace width and length as well as the ratio of the length and width of cheliped merus. The third group of crab is also has similarity about $98-99 \%$ by the Portunus pelagicus 16 S rRNA sequences available in gene banks. These studies had concluded that differences in color and pattern of the spot density have also morphometric and genetic differences. At least there were two groups based on genetic variation of Portunus pelagicus from Barru Regency waters which may have a variety of different properties. Further research is needed to study the adaptation abilities of the two groups of crab on the condition of aquaculture as a potential domestic animal.
\end{abstract}

Keywords: Crab; Morphometric; Portunus pelagicus; 16S rRNA

\section{Introduction}

Blue Swimming Crab (Portunus pelagicus) is one of the important commodities in the world's fisheries. The crabs are valuable seafood of great demand both in domestic markets and the export industry. This crab is found in tropical region and distributed in Indo Pasific Ocean, Mediteranian Sea and east coast of Africa. The crabs lives in a wide range of inshore and continental shelf areas, including sandy, muddy or algal and seagrass habitats, from the intertidal zone to at least $50 \mathrm{~m}$ depth (FAO, 2014). The Crab is exploited by many countries to support the economy (Svane and Hooper, 2004; Sawusdee and Songrak, 2009; Ehsan et al., 2010; Mehanna et al., 2013; Nieves et al., 2013; Gadhavi et al., 2013).

Indonesia is one of the countries are largest exporter of $P$. pelagicus. These crab found abundant in throughout coastal area. The crabs caught from the wild using a trap and gillnet to supply global market. The World bank (2012) reported that in 2008, Indonesia was ranked second largest producer of blue swimmer crab after China with a contribution about $20 \%$.

In almost all countries that producing blue swimming crab, this commodity has been overexploited to supply global demand that continues to increase from year to year (Mehanna et al., 2013; Nieves et al., 2013; Gadhavi et al., 2013). This phenomenon is real perceived by the decline in the fishing catch in terms of both quality and quantity. According to statistics of the fisheries of South Sulawesi Province, in Barru Regency, crab production in 2009-2012 decline an average of 3886.5 tons per year. Overexploitation not only threatens the sustainability of the resource but also threaten livelihoods.

Considering its contribution to the economy and the livelyhood of those who depend on crab fishery, the effort to develop sustainable resource management is very important in order to get attention. Domestication is one way to do that the blue swimming crab harvest not only from wild but also from cultivation. For this purpose, it is necessary to identify the types of crab that has a better potential to be maintained in the brackish water ponds. Based on the reports of fishermen, there are variations in the color of blue swimming crabs from different habitats of Barru waters and they have different vitality.

Morphometric character and DNA has been widely used to determine the relatedness between species, including crustaceans. Quantitative morphometric study has three 
benefits that can distinguish gender and species, describe the patterns of morphological diversity between species, and classify and suspect relationships phylogeny (Overton et al., 1997; Sangthong and Jondeung, 2006). Chang and Hsu (2004) suggested that the ratio of external morphometric characters to examine the genetic variation because is more concrete and accurate. However, it is often difficult to distinguish species morphologically. To overcome these problems, the use of DNA analysis performed (Fratini and Vannini, 2002; Reda et al., 2013). DNA analysis was also used to study the genetic variation and population structure (Imai et al., 1999; Pfeiler et al., 2005; Place et al., 2005). Naim et al. (2012) using DNA Mitochondrial (mtDNA) to study the phylogenetic relationships of mud crab genus Scylla because this crab species are morphologically indistinguishable. Through the phylogenetic relationship of mtDNA sequence can be determined because it allows distinguishing the types of genes (Sunnucks, 2000).

Today, the mitochondrial rRNA was used to identify the species because rRNA gene is more conserved (Yang et al., 2013) and have a higher mutation rate thus enabling produce species-specific (Li et al., 2010). Shih et al. (2004) suggests that the 16S ribosomal RNA (rRNA) of mitochondrial proven effective to phylogeny and population studying of crustacea and to identify of species. Xu et al. (2009) was study the population structure of Portunus trituberculatus used mtDNA 16S rRNA sequences.
The purpose of this study was to analyze the diversity of the crab species found in Barru waters South Sulawesi Indonesia using morphometric and 16SrRNA mitochondrial sequences. The results of this study important as basic information for the selection of the broodstock for the purpose of blue swimming crab domestication.

\section{Materials and Methods}

\section{Specimen collection}

Specimen of Portunus pelagicus collected from Barru Regency waters, South Sulawesi Province, Indonesia. Fresh specimens were collected from fishermen at fishing ports during July 2013 until March 2014. The collected specimens were grouped by color and density spots on carapace differences. The Specimens were preserved in freezer $\left(-20^{\circ} \mathrm{C}\right)$ before analyzed.

\section{Morphometrics}

Seventy five specimens used to morphometric examination. Fourteen measurements were taken (Table 1; Figure 1), and standardized using ratios. Statistical tests were undertaken using SPSS 15.0. Morphometric ratio comparisons between individual males from different groups were carried out with a one way ANOVA and a post hoc Scheffe test for comparison between groups. Canonical discriminant analysis was performed to determine groupings and Test of equality of group means used to determine the character identifier.

Table 1. List of Dimensions Measured and Ratios Used in Morphometric Analysis

\begin{tabular}{|c|c|c|}
\hline No. & Morphometric Character & Ratio \\
\hline 1. & Carapace & \\
\hline \multirow[t]{2}{*}{2.} & Carapace width $(\mathrm{CW})$ & $\mathrm{CW} / \mathrm{CL}$ \\
\hline & Carapace length $(\mathrm{CL})$ & \\
\hline 4. & Cheliped & \\
\hline 5. & Major cheliped means length (MEL) & MEL/MEW \\
\hline 6. & Major cheliped merus Width (MEW) & \\
\hline \multirow[t]{2}{*}{7.} & Major cheliped manus length (MAL) & MAL/DAL \\
\hline & $\begin{array}{l}\text { Major cheliped dactylus length (DAL } \\
\text { Pereiopods }\left(4^{\text {th }}\right)\end{array}$ & \\
\hline 9. & $\begin{array}{l}4^{\text {th }} \text { pereiopod merus length (4PL) } \\
4^{\text {th }} \text { pereiopod merus length }(4 \mathrm{PW})\end{array}$ & 4PL/4PW \\
\hline 10. & Pereiopods $\left(5^{\text {th }}\right)$ & \\
\hline 11. & $\begin{array}{l}\text { Natatory leg dactylus length (NDL) } \\
\text { Natatory leg dactylus length (NDW) }\end{array}$ & NDL/NDW \\
\hline 12. & Abdomen & \\
\hline 13. & Penultimate segment length (PL) & PL/PW \\
\hline \multirow[t]{2}{*}{14.} & Penultimate segment width (PW) & \\
\hline & Telson width (TW) & $\mathrm{PL} / \mathrm{TW}$ \\
\hline
\end{tabular}




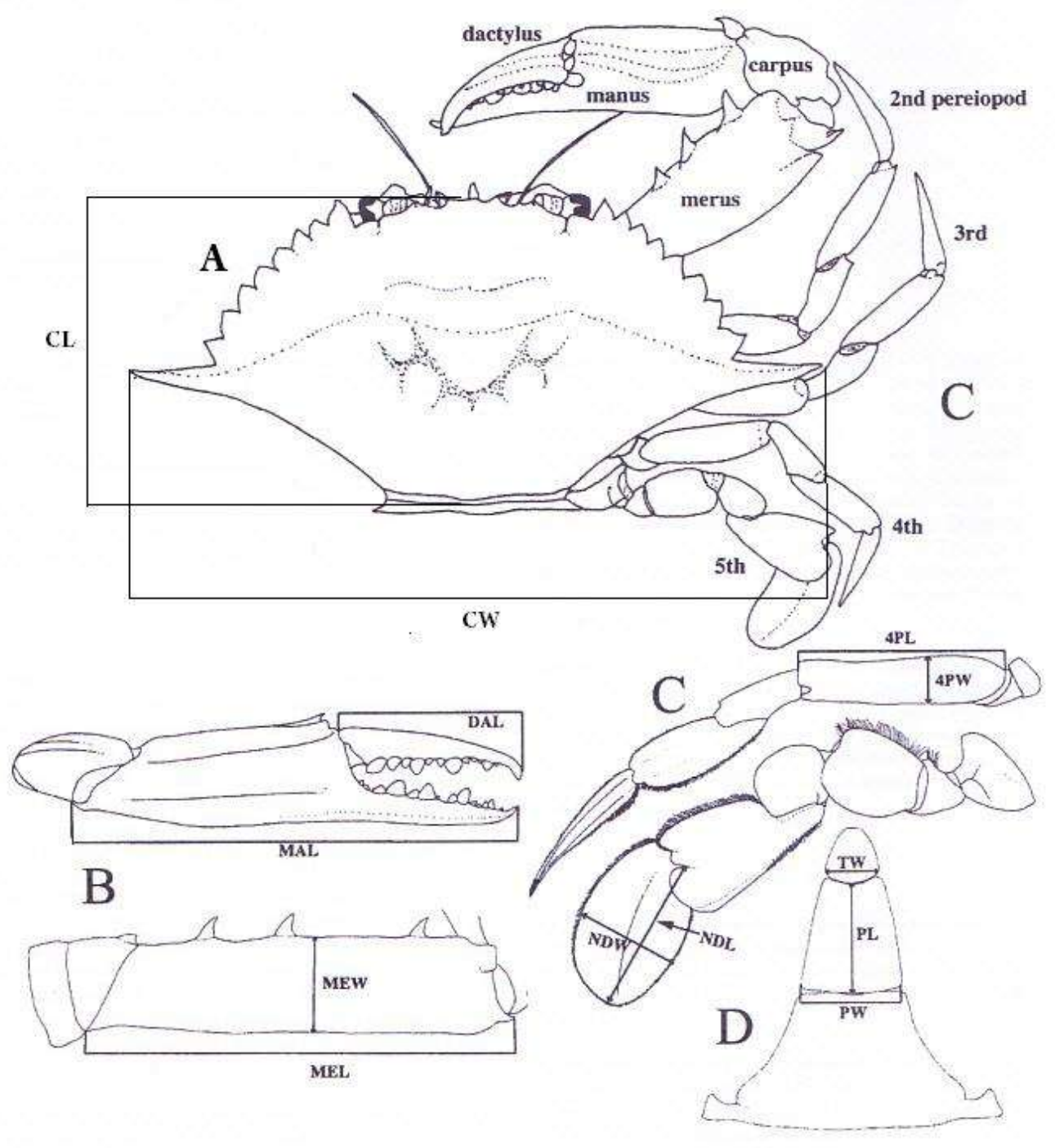

Figure 1. Body parts scheme of Portunus pelagicus and morphology measured in this study. A Carapce and appendages; B Cheliped; C Pereipods; D abdomen (after Lai et al., 2010).

\section{DNA extraction}

Genomic DNA was extracted from the muscle tissue of walking legs or claw using phenol-chloroform (Parenrengi et al., 2000). The Sample were added lysis buffer $(0.5 \mathrm{M} \mathrm{NaCl}$, $0.001 \mathrm{M}$ EDTA, $1 \%$ SDS, $0.8 \%$ Triton-X, and 0.1 Tris- $\mathrm{HCl}$ at $\mathrm{pH} 9.0$ ) and then $40 \mathrm{~mL}$ of $10 \%$ SDS and $40 \mathrm{~mL}$ Proteinase $\mathrm{K}$ (solution 20 $\mathrm{mg} / \mathrm{mL}$ ). Samples were incubated at $55^{\circ} \mathrm{C}$ for $1-3$ $\mathrm{h}$ or until lysis perfect. Then the sample was added $25 \mathrm{~mL}$ RNase (solution $20 \mathrm{mg} / \mathrm{mL}$ ) and allowed to stand at room temperature for 15-30 min. 500-600 mL sample was added phenol: chloroform: isoamyl-alcohol (25:24:1) and then homogenized with a vortex. The samples were left at room temperature for $10 \mathrm{~min}$ before centrifuged at 13,000 rpm for $4 \mathrm{~min}$. Supernatant was transferred to a micro tube is formed and then added another 500-600 mL of phenol: chloroform: isoamyl-alcohol (25:24:1) and centrifuged again at 13,000 rpm speed for $4 \mathrm{~min}$. The supernatant was added one volume with chloroform: isoamyl-alcohol (24:1) and then centrifuged at a speed of 13,000 rpm for $2 \mathrm{~min}$. Subsequently the supernatant was precipitated with cold absolute ethanol by flipping the micro tube and then centrifuged at a speed of 6,000 rpm for $30 \mathrm{~min}$. Formed pellets were washed with 1 $\mathrm{mL}$ of $70 \%$ ethanol and then centrifuged at a speed of 6,000 rpm for $15 \mathrm{~min}$. Dried DNA pellet aired about $20 \mathrm{~min}$, then added with $50 \mathrm{~mL}$ of sterile distilled water (SDW) in order to dissolve the DNA pellet was perfect and then stored in a freezer $\left(-20^{\circ} \mathrm{C}\right)$ until used for further process. To determine the success of the extraction, genomic DNA was mixture with 7.5 цL 2.5 цL Loading Dye and electrophoresed in $0.8 \%$ agarose gel in 1 
$x$ TBE (Tris-Boric acid-EDTA) at a voltage of 50 volts. Gel stained with $0.5 \mathrm{Lg} / \mathrm{mL}$ ethidium bromide solution. Hind III marker was used as a standard marker of genomic DNA extracted.

\section{Mitochondrial 16S rRNA Isolation}

MtDNA fragments isolated from crab genome using mt-DNA-specific primer that is forward 16SrRNA-F: 5'-CGC aaa ctg ttt aac aac at $-3^{\prime}$ and reverse 16SrRNA-R: 5'-CCG act cag tga gtc atc atg $t-3$ '. DNA amplification was performed with a GeneAmp PCR System 2700 (Applied Biosystems, USA). PCR reactions using the kit PureTaq Ready-To-Go Beads (GE Healthcare, USA) containing 2.5 units of Taq polymerase; $10 \mathrm{mM}$ Tris- $\mathrm{HCl}, \mathrm{pH} 9 ; 50 \mathrm{mM} \mathrm{KCl}$; $1.5 \mathrm{mM} \mathrm{MgCl} 2$; and $200 \mathrm{~lm}$ of each dNTP-mix; and each primer plus $50 \mathrm{pmol}$ and sterile water (SDW) to reach a final volume of $25 \mathrm{~mL}$. MtDNA PCR amplification using GeneAmp PCR System 2400 (Applied Biosystems, USA) with the program: $1 \mathrm{~min}$ at $98^{\circ} \mathrm{C}(1$ cycle $)$ and 1 min at $95^{\circ} \mathrm{C}, 1 \mathrm{~min}$ at $55^{\circ} \mathrm{C}$ and $2 \mathrm{~min}$ at $72^{\circ} \mathrm{C}(30$ cycles), and final extension of $5 \mathrm{~min}$ at $72^{\circ} \mathrm{C}$. Product of Mt-DNA amplification as much as 7.5 цL with 2.5 цL loading dye was electrophoresis using $1 \%$ agarose gel. Gel stained with ethidium bromide at a concentration of $0.5 \mathrm{Lg} / \mathrm{mL}$. Digital BioDoc documentation system (Biometra, Germany) used to view the tape of mtDNA successfully amplified. MtDNA fragment size determination made by standard marker $1 \mathrm{~kb}$ DNA ladder.

\section{Mitochondrial 16S rRNA Sequencing}

PCR products were purified amplification product using QIAquick Purification kit (Qiagen, USA). DNA concentration was measured using Bio-Spectro spectrophotometer (Shimazu, Japan). PCR using the primers for sequencing of $16 \mathrm{~S}$ rRNA and specific reagents for DNA sequences (Big Dye). PCR volume of $10 \mathrm{~mL}$ consisting of 1-1.5 DNA Big Dye $2 \mathrm{~mL}, 6 \mathrm{~mL} \mathrm{H} 2 \mathrm{O}$, and $1 \mathrm{~mL}$ primary. PCR cycle consists of three stages: $95^{\circ} \mathrm{C}$ for 15 $\mathrm{min}, 43^{\circ} \mathrm{C}$ for $15 \mathrm{~min}$, and $60^{\circ} \mathrm{C}$ for $240 \mathrm{~min}$. PCR results that have been purified and denatured then sequenced with an ABI Prism 3103 automated tool-Avant Genetic Analyzer (Applied Biosystems, USA). Manually sequencing results seen with the program sequence navigator software (Applied Biosystems).

\section{Data Analysis}

Mt-DNA sequencing results were analyzed using the soft ware GENETYX Version 7 (Genetyx Coorporation) and basic local alignment search tool (BLAST). GENETYX program was used for determination of nucleotide variation and genetic distance between individuals crab. While the online BLAST program particularly BLAST-N is used to determine the mtDNA 16S rRNA sequence similarity (similarity index) and kinship among several species of portunid crab that are available in the GenBank.

\section{Results}

\section{Morphometric}

Morphological characters of three groups of Portunus pelagicus based on different color and spotted pattern was determined (Figure 2). Statistical analysis of measurement of 14 morphometric characters can be seen in the Table 2 . These data were used for discriminant analysis.
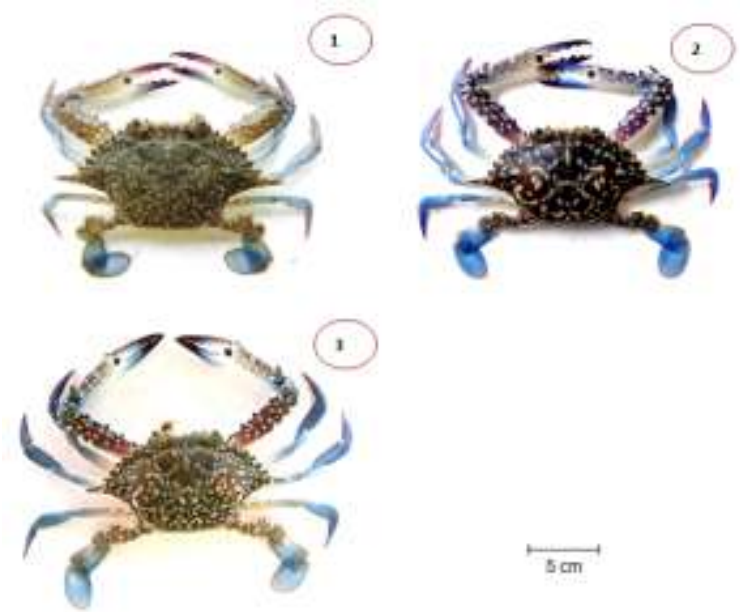

Figure 2. Three groups of collected specimens. Body color is light blue, white spot pattern on carapace is full (Group-1), body color is purple, pattern of white spots on carapace are rarely (Group-2), body color is purple greenish, large white spots scatter on carapace with medium density (Group-3). 
Table 2. Morphometric measurement of three groups of Portunus pelagicus

\begin{tabular}{lcccccc}
\hline \multirow{2}{*}{\begin{tabular}{c} 
Measurement $(\mathrm{cm})$ \\
\cline { 2 - 7 }
\end{tabular}} & \multicolumn{2}{c}{ Group-1 $(\mathrm{n}=25)$} & \multicolumn{2}{c}{ Group-2 $(\mathrm{n}=25)$} & \multicolumn{2}{c}{ Group-3 $(\mathrm{n}=25)$} \\
\hline CW/CL & $2.371 \pm 0.084$ & $2.184-2.513$ & $2.101 \pm 0.219$ & $1.260-2.422$ & $2.316 \pm 0.077$ & $2.153-2.476$ \\
MEL/MEW & $3.916 \pm 0.369$ & $3.364-4.545$ & $4.447 \pm 0.506$ & $3.643-5.462$ & $4.219 \pm 0.362$ & $3.364-4.667$ \\
MAL/DAL & $2.130 \pm 0.256$ & $1.348-2.353$ & $2.208 \pm 0.104$ & $1.920-2.370$ & $2.245 \pm 0.202$ & $1.348-2.393$ \\
PL4/PW4 & $5.373 \pm 0,540$ & $4.800-6.500$ & $5.256 \pm 0.967$ & $3.571-9.000$ & $5.208 \pm 0.628$ & $3.571-6.500$ \\
NDL/NDW & $1.830 \pm 0.306$ & $1.000-2.125$ & $1.870 \pm 0.339$ & $1.040-2.727$ & $1.776 \pm 0.377$ & $1.000-2.600$ \\
PL/PW & $1.004 \pm 0.076$ & $0.889-1.125$ & $0.982 \pm 0.077$ & $0.846-1.182$ & $0.970 \pm 0.173$ & $0.204-1.125$ \\
PL/TW & $2.334 \pm 0.394$ & $1.800-3.000$ & $2.221 \pm 0.334$ & $1.571-3.000$ & $2.270 \pm 0.367$ & $1.571-3.000$ \\
\hline
\end{tabular}

Canonical discriminant analyses showed big morphometric differences $(P<0.05)$ among the three groups. Group-1 was significantly different from group-2, but less different from group-3. Canonical discriminant functions analysis showed clear grouping with different centroid (Figure 3). there was a portion in the plot distribution pattern was piled-up each other, which indicated some characters were identical between the three populations. Based on Functions at Group Centroids, the three populations occupied different axis (Figure 4). However, group-1 and 3 occupied on negative axis and group-2 laid on the positive axis. This indicated that group-2 was far distance from group-1 and 3.

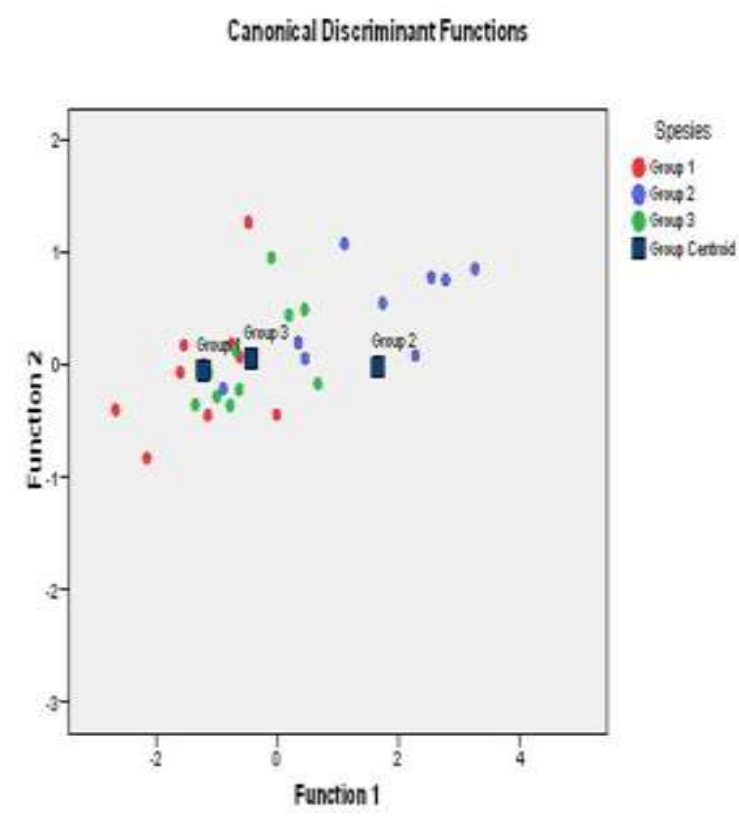

Figure 3. Scatter Plot Canonical Discriminant Functions between Three Groups of Portunus pelagicus Based on the Morphometric Character

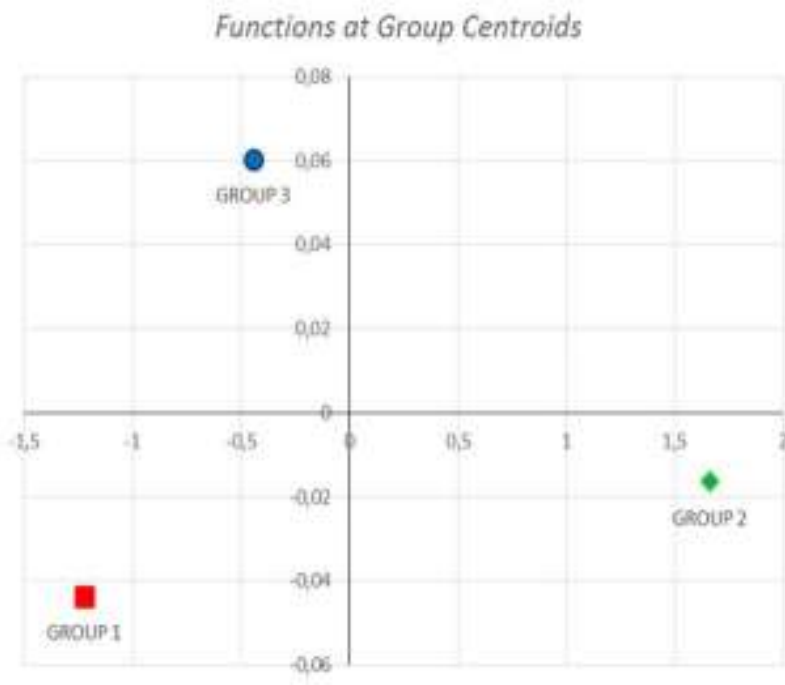

Figure 4. Functions at Group Centroids between Three Groups of Portunus pelagicus Based on the Morphometric on the Flat Field

Based on the Test of equality of group means showed that main differentiator was found on the two characters, 1) ratio between carapace width to carapace length (CW/CL) (df $=2, \mathrm{~F}=$ 4.963, $P<0.05)$ and 2) ratio between merus cheliped length to merus cheliped width $(\mathrm{MEL} / \mathrm{MEW})(\mathrm{df}=2, \mathrm{~F}=9.196, P<0.05)$. These ratio indicated that carapace shape of $P$. pelagicus from group-2 was more spherical than group-1 and group-3. Cheliped shape of crab from group-1 was shorter and fatter compared to cheliped from group-2 and group- 3 . The cheliped from group-2 and group-3 was longer and slender (Table 2).

\section{Aligment of 16S rRNA Sequences}

Extraction of DNA genome from three groups of Portunus pelagicus by phenolchloroform conventional method was successfully performed. Electrophoresis of $16 \mathrm{~S}$ rRNA mtDNA the crab showed single band on 
the position of 625 basepair (Figure 5). The size of the mithocondrial large ribosomal subunit rRNA (16S rRNA) of $P$. pelagicus is slightly larger than the 16S rRNA of Varunidae that is 580 basepair region (Schubart et al., 2001), although equally brachyura.

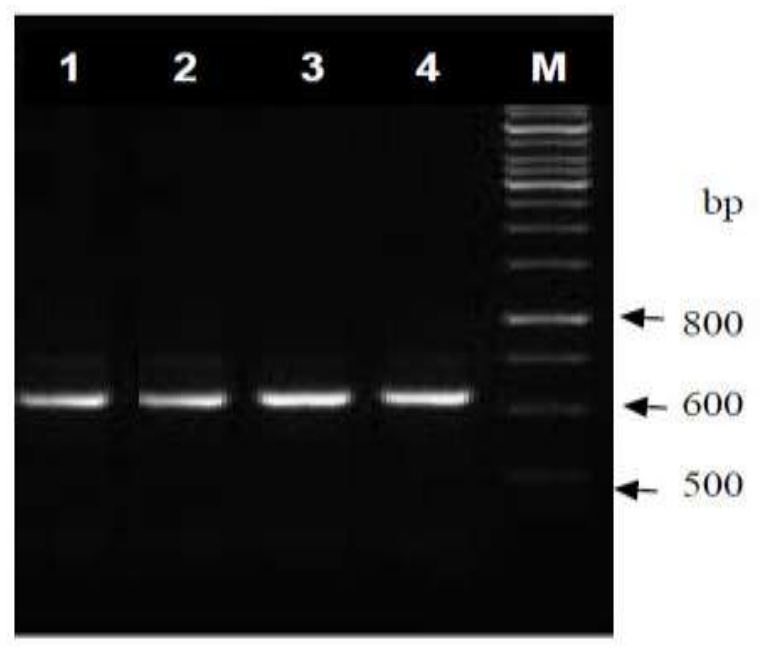

Figure 5. Electrophoresis of DNA fragments isolated from the blue swimming crab $16 \mathrm{~S}$ rRNA (1-4=blue swimming crab sample, $\mathrm{M}=$ DNA marker)
Alignment of 16S rRNA sequence from three groups of $P$. pelagicus from Barru Regency Waters show that the differences of DNA sequences from the 16S rRNA gene (Figure 6). Equality analysis between crab samples showed high (98-99\%) homology of 16S rRNA nucleotide gene. This indicated that the three groups were come from one species. However, cluster analysis showed genetic closeness was found on group-1 and group-3 and farthest kinship relationship was on group-2 (Figure 7).

Nucleotide BLAST analysis showed that the crab samples have high similarity (96-99\%) to species of Portunus pelagicus in genbank (Accession numbers: DQ062734.1, FM208750.1, FJ152161.1， KF220520.1， KF220521.1, KF220519.1， FJ812329.1， DQ388052.1). Meanwhile, comparison of nucleotide similarity to other portunid crabs such as $P$. trituberculatus (Accession number: FJ919807.1, GQ180777.1, DQ062735.1, AY264913.1, AY264913.1) have 94-95\% similarity, P. sanguinolentus (Accession number: KF220524.1, KF220522.1, KF220525.1, KF220526.1, KF220523.1) have lower similarity (93-94\%), and with P. sayi (Accession number: DQ388053.1) have lowest similarity (93\%).

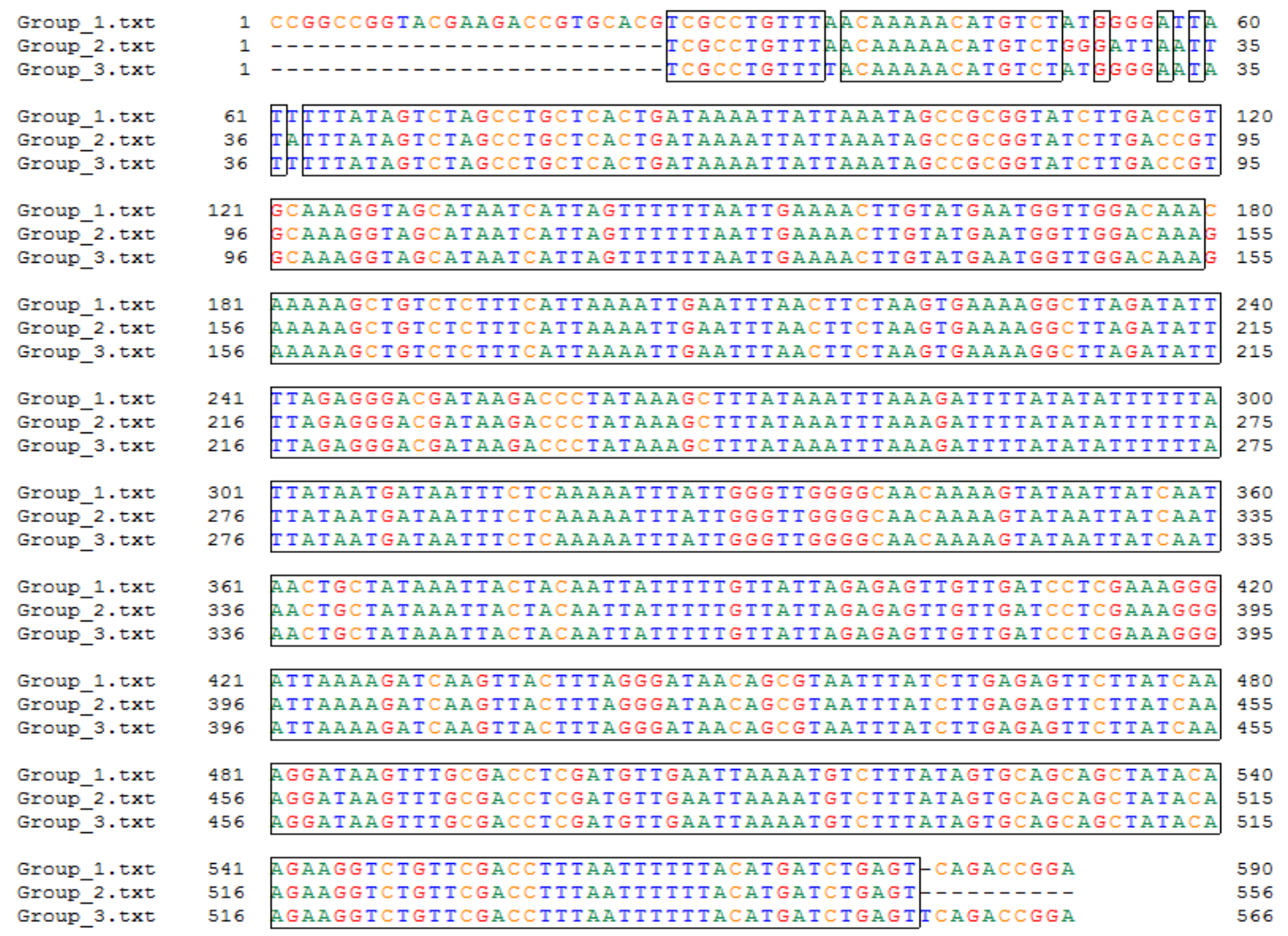

Figure 6. Alignment of 16S rRNA Sequence from Three Groups of Portunus pelagicus (A=Adenine, $\mathrm{T}=$ Thymine, $\mathrm{G}=$ Guanine, $\mathrm{C}=$ Citosine, and square box means nucleotide similarity). 


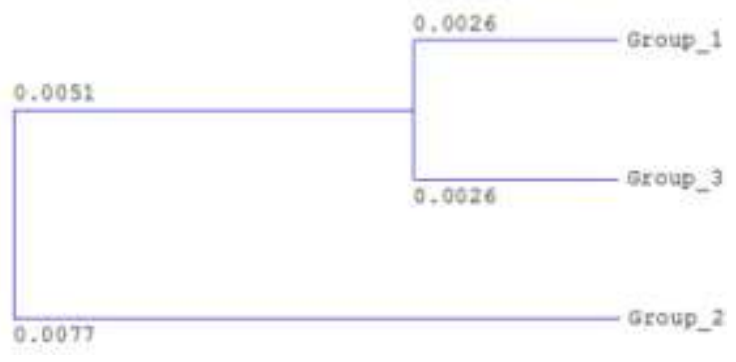

Figure 7. Dendogram of Intra-Species of Three Groups of Portunus pelagicus from Barru Regency Waters Based on the Sequence of 16S rRNA Gene.

\section{Discussions and conclusions}

Color difference is previously believed caused by habitat condition, apparently is not fully true. Color differences and spot pattern on carapace of $P$. pelagicus was also reflected in the morphometric difference which is believed caused by genetically difference. Mistaken of perception on color difference occurred on the mud crab identification. It had been very long period that genus of Scylla was consisted only one species that was Scylla serrata. Color variation among mudcrab was believed merely because of habitat difference. To discover the phenomenon, Overton et al. (1997) conducted a multivariate analysis from morphometric and meristic character of "black" and "white" color of mud crab from four locations in Southeast Asian. Surprisingly, based on the Canonical variate analysis (CVA) showed that "black" color of mud crab group was different from "white" color. Then, Keenan et al. (1998) emphasized that color difference of the mud crab was caused by differences in genetic after performing a combination between morphometric and DNA analysis of complexity of mud crab species Scylla serrata. After that, the mudcrab species was revised into four species, S. serrata, S. olivacea, S. tranquebarica, and $S$. paramamosain.

Shape differences on the $P$. pelagicus were first reported by Bryars and Adams (1999), one type was widely distributed in Australia and the other type was found only around Darwin of Australia. In 2010, Lai et al. (2010) revised the portunid crab sistematic based on the morphometric and DNA analysis. They were proposed a revision that portunid crab that was currently known as Portunus pelagicus apparently was consisted of four species, P. Pelagicus, $P$. segins, $P$. reticulatus, and $P$. armatus.
Unfortunately, color and spot pattern characteristics of $P$. pelagicus from Barru Regency South Sulawesi Indonesia was entirely accomodated by Lai et al. (2010) revision and apparently, morphometrically the three groups were different based on the Canonical discriminant analysis. The $P$. pelagicus found in Barru Regency waters was similar to $P$. reticulatus with group-1 and $P$. pelagicus with Group-3 but Group-2 was mentioned in the revision. According to Lai et al. (2010) $P$. reticulatus was mentioned that had shorter and fatter merus cheliped and $P$. pelagicus had relatively longer and thinner merus cheliped which was similar to the crab from group- 1 and group-3 in these study. There was a possibility that the population belonging to the group- 2 has undergone mutation or is the result of hybridization. Lai et al. (2010) also reported a phenomenon of natural hybridization between $P$. pelagicus and $P$. reticulatus in the Bay of Bengal.

Morphometrically differences of this study were strengthening by sequence of $16 \mathrm{~S}$ rRNA analysis. Even though, the difference among three groups is quite small $(1-2 \%)$, but could be assumed that there is an intraspecific variation in P. pelagicus. Mantelatto et al. (2007) reported that based on the analysis of 16S rRNA sequence of Portunus genus in the Western Atlantic, there were at least three different groups and there will taxonomic revision. Klinbunga et al. (2010) also reported that in the Thailand waters there was an intraspecific variation of $P$. Pelagicus population in the same geographic location.

If the species revision proposed by Lai $e t$ al. (2010) is accepted, then the crab of group-2 in this study was suspected a different species of $P$. pelagicus. Therefore, probably species of $P$. pelagicus is consisted of more than four species as proposed by Lai et al. (2010) or only two species as reported Sienas et al. (2014) that $P$. pelagicus occuring across the entire Philippine archipelago potential consists of 2 species. This argument is based on the cluster analysis which is described on the dendogram as seen on the Figure 7. The dendogram shows genetic closeness is found from group-1 and 3, and furthest kinship relationship is in the group-2. Sienas et al. (2014), based on the result of mitochondrial Cytochrome oxidase subunit I (COI) gene region study, reported that $P$. pelagicus in the Philippines possible 'cryptic' Portunus species where the morphological appearance was 
incapable to distinguish between species. However, there is still need further study to confirm this assumption.

These studies had concluded that differences in color and pattern of the spot density have also morphometric and genetic differences. At least there were two groups based on genetic variation of Portunus pelagicus from Barru Regency waters which may have a variety of different properties. Further research is needed to study the adaptation abilities of the two groups of crab on the condition of aquaculture as a potential domestic animal.

\section{Acknowledgements}

This research was funded by Indonesia Ministry of Education and Culture through Grant for Excellent Research for National Strategic. The authors are grateful to the Research Institute for Coastal Aquaculture for DNA analysis facility.

\section{References}

Bryars, S.R. and M. Adams. 1999. An allozyme study of the blue swimmer crab, Portunus pelagicus (Crustacea: Portunidae), in Australia: stock delineation in southern Australia and evidence for a cryptic species in northern waters. Australian Marine and Freshwater Research, 50(1): 15-26.

Chang, H.C. and C.H. Hsu. 2004. Statistical comparisons of some external morphometrical aspects of the swimming crab Portunus sanguinolentus (Herbst) populations inhabiting the Keelung Shelf and Taiwan Bank. TAO, 15(2): 179-197.

Ehsan, K., S.A. Nabi, and Y. Maziar. 2010. Stock assessment and reproductive biology of the blue swimming crab, Portunus pelagicus in Bandar Abbas Coastal Waters, Northern Persian Gulf. Journal of the Persian Gulf, 1(2): 11-22.

FAO. 2014. Species fact sheets Portunus pelagicus (Linnaeus, 1758). Fisheries and Aquaculture Department.

Fratini, S. and M. Vannini. 2002. Genetic differentiation in the mud crab Scylla serrata (Decapoda: Portunidae) within the Indian Ocean. J. Exp. Mar. Biol. Ecol., 272: 103116.

Gadhavi, M.K., H.K. Kardani, P. Rajal, P.C. Prajapati, and K.D. Vachhrajani. 2013. Impact of trawl fish ban on artisanal brachyuran crab fishery in and around Sikka, Gulf of Kutch, Gujarat, India. Res. J. Animal, Veterinary \& Fishery Sci., 1(1): 22-27.
Imai, H., Y. Fuji, J. Karakawa, S. Yamamoto, and K. Numachi. 1999. Analysis of the population structure of the swimming crab Portunus trituberculatus in the Coastal Waters of Okayama Prefecture, by RFLPs in the Whole region of mitochondrial DNA. Fisheries Science, 65(4): 655-656.

Keenan, C.P., P.J.F. Davie, and D.L. Mann. 1998. A Revision of the genus Scylla De Haan, 1983 (Crustasea: Decapoda: Brachyura: Portunidae). The Raffles Bulletin of Zoology, 46 (1): 217-245.

Klinbunga, S., V. Yuvanatemiya, S. Wongphayak, K. Khetpu, P. Menasveta, and B. Khamnantong. 2010. Genetic population differentiation of the blue swimming crab Portunus pelagicus (Portunidae) in Thai waters revealed by RAPD analysis. Genetics and Molecular Research, 9(3):1615-1624.

Lai, J.C.Y., P.K.L. Ng, and P.J.F. Davie. 2010. A Revision of The Portunus pelagicus (Linnaeus, 1758) Species Complex (crustacea: brachyura: portunidae), With The Recognition of Four Species. The Raffles Bulletin of Zoology, 58(2):199-237.

Li, X., J.F. Cai, Y.D. Guo, K.L. Wu, J.F. Wang, Q.I. Liu, X.H. Wang, Y.F. Chang, L. Yang, L.M. Lan, M. Zhong, X. Wang, C. Song, Y. Liu, J.B. Li, and Z.H. Dai. 2010. The availability of $16 \mathrm{~S}$ rRNA for the identification of forensically important flies (Diptera: Muscidae) in China. Tropical Biomedicine, 27(2): 155-166.

Mantelatto, F.L., R. Robles, and D.L. Felger. 2007. Molecular phylogeny of the western atlantic species of the genus Portunus (Crustacea, Brachyura, Portunidae), Zoological Journal of the Linnean Society, 150: 211-220.

Mehanna, S.F., S. Khvorov, M. Al-Sinawy, Y.S. AlNadabi, and M.N. Al-Mosharafi. 2013. Stock assessment of the blue swimmer crab Portunus pelagicus (Linnaeus, 1766) from the Oman Coastal Waters. International Journal of Fisheries and Aquatic Sciences, 2(1): 1-8.

Naim, D.M., H.A.A.M. Rosly, and S.A.M. Nor. 2012. Assessment of phylogenetic interrelationships in mud crab Genus Scylla (Portunidae) based on mitochondrial DNA sequence. International Conference on Applied Life Sciences. Turkey, September 10-12, 2012.

Nieves, P.M., S.D. Jesus, M.A.B. Gulriba, A.M.B. Macale, S. Belen, and G. Corral. 2013. Capture fisheries assessment of commercially important marine crabs in Sorsogon Bay and San Miguel Bay. Kuroshio Science, 7(1): 5967.

Overton, J.L., D.J. Macintosh, and R.S. Thorpe. 1997. Multivariate analysis of the mud crab 
Scylla serrata ( Brachyura: Portunidae) from four location in Southest Asia. Mar. Biol., 128: 55-62.

Parenrengi, A., L. Shamsudin, P. Ismail, and N.M. Amin. 2000. Preliminary study on DNA level marker of grouper at different buffer preservation and DNA extraction method. In Saad MS, Faridah QZ, Kadir MA., Khalid MZZ, Mohamad O, Saleh GB, Panandam JM (Editors). Genetic Manipulation: Challenges and Advantages. Proceeding of the $4^{\text {th }}$ National Congress on Genetics, 26-28 Sept.2000, Genting Highlands, Malaysia, p.194-208.

Place, A.R., X. Feng, C.R. Steven, H.M. Fourcade, and J.L. Boore. 2005. Genetic marker in blue crabs (Callinectes sapidus) II. Complete mitochondrial genome sequence and characterization of genetic variation. J. Exp. Mar. Biol. Ecol., 319: 15-27.

Pfeiler, E, L.A. Hurtado, L.L. Knowles, J. TorreCosio, L. Bourilon-Moreno, J.F. MarquezFarias, and G. Montemayor-Lopez. 2005. Population genetics of the swimming crab Callinectes bellicosus (Brachyura: Portunidae) from the eastern Pacific Ocean. Mar. Biol., 146: 559-569.

Reda, F.A.B., M.A. Gesraha, N.A.M. Guneidy, N.A.E. Farag, A.R. Ebeid, H.H.A. Elbehery, and M. Abou-Ellail. 2013. Molecular genetic identification of two bracon species based on RAPD-PCR and 16S rRNA genes. Egypt. Acad. J. Biolog. Sci., 5(2):99-107.

Sangthong, P. and A. Jondeung. 2006. Classification of three mud crab morphs in the genus Scylla using morphometric analysis. Nat. Sci., 40: 958-970.

Sawusdee, A. and A. Songrak. 2009. Population Dynamics and Stock Assessment of Blue Swimming Crab (Portunus pelagicus
Linnaeus, 1758) in the Coastal Area of Trang province, Thailand. Walailak J. Sci. \& Tech., 6(2):189-202.

Shih, H.T., K.L.N. Peter, and H.W. Chang. 2004. Systematics of the genus Geothelphusa (Crustacea, Decapoda, Brachyura, Potamidae) from Southern Taiwan: A molecular appraisal. Zoological studies, 43(3): 561-570.

Sienas, P.M.Q., D.A. Willette, L.R. Romena, C.G. Alvior, and J.S. Estacion. 2014. Genetic diversity and the discovery of putative cryptic species within a valued crab fishery, Portunus pelagicus (Linnaeus 1758) in the Philippines, Philippine Science Letters, 7(2):317-323.

Sunnucks, P. 2000. Efficient genetic markers for population biology. Trend in Ecology and Evolution, 15: p. 199-203.

Svane, I. and G. Hooper. 2004. Blue swimmer crab (Portunus pelagicus) fishery. Fishery assessment report to PIRSA for the blue crab fishery management committee. SARDI Aquatic Science Publication No: RD03/02742.

World Bank. 2012. Evaluation of New Fishery Performance Indicators (Fpis): A Case Study Of The Blue Swimming Crab Fisheries In Indonesia And Philippines. International Bank For Reconstruction And Development / International Development Association. Washington Dc 20433.

Xu, Q., R. Liu, and Y. Liu. 2009. Genetic population structure of the swimming crab, Portunus trituberculatus in the East China Sea based on mtDNA 16S rRNA sequences. J. Exp. Mar. Biol. Ecol., 371(2), 121-129.

Yang, L., Z. Tan, D. Wang, L. Xue, M. Guan, T. Huang, and R. Li. 2013. Species identification through mitochondrial rRNA genetic analysis. Scientific reports, 4:1-11. 